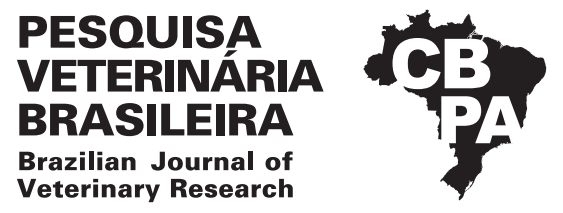

Pesq. Vet. Bras. 38(9):1781-1786, setembro 2018 DOI: 10.1590/1678-5150-PVB-5169

Original Article

ISSN 0100-736X (Print)

ISSN 1678-5150 (Online)

\title{
Blood lactate increases with the progression of mitral valve disease in dogs $^{1}$
}

\author{
Jorge Cardoso Silva-Filho², Marlos G. Sousa ${ }^{3 *}$, Evandro Zacché Pereira², \\ Edna M.G. Ortiz ${ }^{2}$, Rodrigo P. Franco ${ }^{2}$, Fernando A. Rosa ${ }^{2}$ \\ and Aparecido Antonio Camacho ${ }^{2}$
}

\begin{abstract}
Silva-Filho J.C., Sousa M.G., Zacché Pereira E., Ortiz E.M.G., Franco R.P., Rosa F.A. \& Camacho A.A. 2018. Blood lactate increases with the progression of mitral valve disease in dogs. Pesquisa Veterinária Brasileira 38(9):1781-1786. Departamento de Medicina Veterinária, Universidade Federal do Paraná, Rua dos Funcionários 1540, Cabral, Curitiba, PR 80035-050, Brazil. E-mail: marlos98@ufpr.br

In dogs with congestive heart failure, the upregulated sympathetic tone causes vasoconstriction that impairs peripheral blood supply, therefore causing the accumulation of lactate. In this prospective cross-sectional study with a longitudinal component, blood lactate was quantified in 10 healthy and 34 myxomatous mitral valve disease (MMVD) dogs to investigate its potential use as a diagnostic and prognostic biomarker. While there were no differences in lactate concentration between control animals and stages B1 $(3.31 \pm 0.62 \mathrm{mmol} / \mathrm{L})$ and B2 $(3.32 \pm 0.46 \mathrm{mmol} / \mathrm{L})$ dogs, significant differences were found between healthy $(2.50 \pm 0.69 \mathrm{mmol} / \mathrm{L})$ and both $\mathrm{C}(3.99 \pm 0.47 \mathrm{mmol} / \mathrm{L})$ and $\mathrm{D}(6.97 \pm 1.23 \mathrm{mmol} / \mathrm{L})$ animals. When a cut-off of $3.35 \mathrm{mmol} / \mathrm{L}$ was used, lactate was able to distinguish dogs with normal and remodeled hearts with a sensitivity of $78.2 \%$ and specificity of $63.6 \%$. Also, significant correlations existed between lactate and indicators of cardiac remodeling. Finally, animals with blood lactate $<3.5 \mathrm{mmol} / \mathrm{L}$ carried a better prognosis when compared with dogs in which lactate was $>5.0 \mathrm{mmol} / \mathrm{L}$. Our results suggest that the progression of MMVD results in accumulation of lactate within the bloodstream, which is likely attributable to the impaired peripheral tissue perfusion. In MMVD dogs, blood lactate may be used as a surrogate for cardiac remodeling, and an increased concentration is associated with a worse prognosis regarding the time to evolve into congestive heart failure.
\end{abstract}

INDEX TERMS: Blood lactate, mitral valve disease, dogs, hyperlactatemia, hypoperfusion, congestive heart failure, myxomatous mitral valve disease, endocardiosis.

\footnotetext{
RESUMO.- [Aumento de lactato sanguíneo com progressão de valvopatia mitral em cães.] Em cães com insuficiência cardíaca congestiva, o tônus simpático hiperregulado causa vasoconstrição e interfere com o suprimento sanguíneo periférico, resultando no acúmulo de lactato. Neste estudo prospectivo transversal com um componente longitudinal, o lactato sanguíneo foi quantificado em 10 cães saudáveis e 34 cães com doença mixomatosa da valva mitral (DMVM)

${ }^{1}$ Received on May 23, 2017.

Accepted for publication on August 21, 2017.

${ }^{2}$ Departamento de Medicina Veterinária e Cirurgia, Faculdade de Ciências Agrárias e Veterinárias, Universidade Estadual Paulista (Unesp), Via de Acesso Prof. Paulo Donato Castelane, Vila Industrial, Jaboticabal, SP 14884-900, Brazil.

${ }^{3}$ Departamento de Medicina Veterinária, Universidade Federal do Paraná (UFPR), Rua dos Funcionários 1540, Cabral, Curitiba, PR 80035-050, Brazil. *Corresponding author: marlos98@ufpr.br
}

para investigar seu potencial como biomarcador diagnóstico e prognóstico. Embora não tenham sido identificadas diferenças na concentração de lactato entre animais controle e cães com DMVM nos estágios B1 $(3,31 \pm 0,62 \mathrm{mmol} / \mathrm{L})$ e B2 $(3,32 \pm 0,46 \mathrm{mmol} / \mathrm{L})$, diferenças significativas foram constatadas entre os cães saudáveis $(2,50 \pm 0,69 \mathrm{mmol} / \mathrm{L})$ e cães com DMVM estágio C $(3,99 \pm 0,47 \mathrm{mmol} / \mathrm{L})$ ou D $(6,97 \pm 1,23 \mathrm{mmol} / \mathrm{L})$. Quando utilizado o valor de corte de $3,35 \mathrm{mmol} / \mathrm{L}$, o lactato foi capaz de diferenciar cães com corações normais daqueles com corações remodelados com sensibilidade de $78,2 \%$ e especificidade de $63,6 \%$. Além disso, correlações significativas foram encontradas entre o lactato e os indicadores de remodelamento cardíaco. Por fim, os animais com lactato sanguíneo $<3,5 \mathrm{mmol} / \mathrm{L}$ tiveram prognóstico melhor comparativamente aos cães com concentrações $>5,0 \mathrm{mmol} / \mathrm{L}$. Nossos resultados sugerem que a progressão da DMVM resulta no acúmulo de lactato 
na corrente sanguínea, fato que é provavelmente atribuído à perfusão periférica prejudicada. Em cães com DMVM, o lactato sanguíneo pode ser utilizado como indicador de remodelamento cardíaco, cuja concentração elevada está associada com pior prognóstico relativo ao tempo para evoluir para insuficiência cardíaca congestiva.

TERMOS DE INDEXAÇÃO: Lactato sanguíneo, valvopatia mitral, cães, hiperlactatemia, hipoperfusão, insuficiência cardíaca congestiva, doença valvar mitral, endocardiose.

\section{INTRODUCTION}

Lactate is an organic product resulting from the anaerobic metabolism of carbohydrates. Under physiologic conditions, it is produced by red blood cells, skeletal muscle, brain, and intestines, while its metabolism occurs at the kidneys and the liver, so that it is used as an additional source of energy for the body (Nel et al. 2004).

Since the biochemical energy system of mammals is based on an aerobic pathway, situations that cause a reduction in oxygen availability to the tissues are likely to require anaerobic pathways to take place, therefore increasing the production of lactate. When the intracellular concentration of lactate increases, the gradient across the cell membranes overwhelms the tissues that are responsible for its degradation, leading to a circulatory overload, eventually resulting in hyperlactatemia and acidosis (Sharkey \& Wellman 2013) Therefore, lactate may be considered an indicator of peripheral tissue hypoperfusion, which might play an important prognostic role in people and animals undergoing several critical conditions. For instance, the augmentation of human blood lactate levels was demonstrated to correlate with a higher incidence of multiple organ dysfunctions (Friedman et al. 1995, Helliksson et al. 2016)

In heart failure patients, the inability to maintain cardiac output along with a strong activation of the cardiovascular compensatory mechanisms causes an inappropriate blood distribution throughout the body. However, little information is available regarding the accumulation of blood lactate in dogs with congestive heart failure. We hypothesized that a prolonged peripheral tissue hypoperfusion related to the activation of compensatory mechanisms would increase the production of lactate, resulting in hyperlactatemia in dogs with mitral insufficiency and congestive heart failure. Therefore, the specific objectives of this study were four-fold: to investigate the concentration of lactate in dogs with myxomatous mitral valve disease (MMVD) and varying degrees of congestive heart failure; to determine its sensitivity and specificity to distinguish dogs with remodeled hearts from those without congestion; to determine whether the blood concentration of lactate would correlate with the results of routine cardiac ancillary tests; and finally, to investigate its prospective use as a prognostic biomarker in these animals.

\section{MATERIALS AND METHODS}

Animals. 137 dogs with myxomatous mitral valve disease (MMVD) were examined. However, only 34 dogs (6-14y; $13.3 \pm 1.2 \mathrm{~kg}$ ) were enrolled into this prospective cross-sectional observational study with a longitudinal component due to MMVD-only exclusion criteria, as well as the exclusion of animals with a history of ongoing medical therapy prior to the study. Also, 10 age-matched (6-12y; $9.6 \pm 5.4 \mathrm{~kg}$ ) healthy dogs were included to serve as controls. The MMVD dogs were subdivided in stages in accordance with the American College of Veterinary Internal Medicine (ACVIM) consensus statement classification (Atkins et al. 2009). Stages B1 ( $\mathrm{n}=11 ; 6-12 \mathrm{y} ; 14.3 \pm 5.3$ $\mathrm{kg}), \mathrm{B} 2$ ( $\mathrm{n}=10 ; 8-13 \mathrm{y} ; 6.4 \pm 2.1 \mathrm{~kg}), \mathrm{C}(\mathrm{n}=9 ; 8-14 \mathrm{y} ; 9.4 \pm 5.0 \mathrm{~kg})$, and D $(\mathrm{n}=4 ; 9-14 \mathrm{y} ; 4.9 \pm 0.9 \mathrm{~kg})$ were represented. Owner written consent was obtained for every animal recruited for the study, which was entirely conducted in accordance with guidelines outlined in the National Institutes of Health Guide for the Care and Use of Laboratory Animals.

Blood lactate and cardiac evaluation. Jugular vein blood was drawn to determine the concentration of lactate, which was performed immediately using a point-of-care lactate analyzer (Accutrend Lactato, Roche Diagnostica Brasil). Only for stage D dogs two other blood samples were obtained from the cephalic vein at admittance and 24 hours later. Also, every dog underwent a complete physical examination and cardiac ancillary tests, which included an echocardiogram (assessment of cardiac morphology, transvalvular blood flow velocities, systolic and diastolic function surrogates), electrocardiogram (heart rate and wave morphology), chest radiograph (VHS), and non-invasive blood pressure assessment (Doppler) as described elsewhere. (Tilley 1992, Buchanan \& Bucheler 1995, Wolf et al. 2000, Boon 2011).

Body temperature gradient. Rectal and peripheral temperatures were acquired using a digital rectal thermometer and an infrared thermometer respectively. The peripheral temperature was obtained with the infrared beam directed towards one of the right forelimb's interdigital areas, which was thoroughly cleaned and dried with a soft tissue immediately prior to acquisition. Temperature was acquired in triplicate, and the average value was considered as the final result. Once peripheral and rectal temperatures had been acquired, a gradient was calculated $(\Delta \mathrm{T})$ representing the difference between them (Vincent et al. 1988, Lima et al. 2009).

Statistical analyses. All data underwent a Shapiro-Wilk normality test, followed by an unpaired T test to check for differences between healthy and MMVD dogs. Also, an analysis of variance was used to document differences between controls and the several MMVD stages. Sensitivity and specificity of blood lactate concentration to differentiate between dogs with remodeled hearts (stages B2, C and D) and those with no cardiac remodeling (B1), were determined using a receiver operating characteristic curve. Pearson's correlation was used to investigate correlations between lactate concentration and several parameters derived from the routine cardiology ancillary methods. A Kaplan-Meier curve was used to evaluate the prognostic value of lactate regarding either the development of clinical signs attributable to CHF or the all-cause mortality. To do so, owners were called at 12 and 18 months after initial evaluation, unless animals were readmitted to hospital due to any other clinical conditions.

\section{RESULTS}

Significant differences $(\mathrm{P}=0.0021)$ were documented between the blood lactate of control dogs $(2.50 \pm 0.69 \mathrm{mmol} / \mathrm{L})$ and dogs with MMVD $(3.92 \pm 1.32 \mathrm{mmol} / \mathrm{L})$ regardless of its stage classification. When a multiple comparisons test was used to further analyze MMVD dogs according to the disease severity stage (Fig.1), significant differences were identified between healthy and both stages C $(3.99 \pm 0.47 \mathrm{mmol} / \mathrm{L})$ and D $(6.97 \pm 1.23 \mathrm{mmol} / \mathrm{L})$ dogs. On the contrary, no differences existed 
between control animals and stages B1 $(3.31 \pm 0.62 \mathrm{mmol} / \mathrm{L})$ and B2 $(3.32 \pm 0.46 \mathrm{mmol} / \mathrm{L})$ dogs.

The most expressive difference between MMVD dogs with normal and remodeled hearts (AUC: 0.7292) was documented with a cut-off of $3.35 \mathrm{mmol} / \mathrm{L}$ (sensitivity: 78.2\%; specificity: 63.6\%) (Fig.2). Significant positive correlations were found to exist between blood lactate concentration and several parameters documented on ancillary tests, including the indexed left ventricular end-diastolic diameter $(\mathrm{R}=0.3348 ; \mathrm{P}=0.0263)$, left-atrium-to-aorta ratio $(\mathrm{R}=0.5840 ; \mathrm{P}<0.0001)$, fractional shortening $(\mathrm{R}=0.3009$; $\mathrm{P}=0.0471)$, average heart rate $(\mathrm{R}=0.3890 ; \mathrm{P}=0.0108)$, the vertebral heart scale $(R=0.5674 ; \mathrm{P}<0.0001)$, and the $\mathrm{P}$ wave amplitude $(\mathrm{R}=0.3485 ; \mathrm{P}=0.0220)$. Also, a negative significant correlation was demonstrated between lactate and systolic

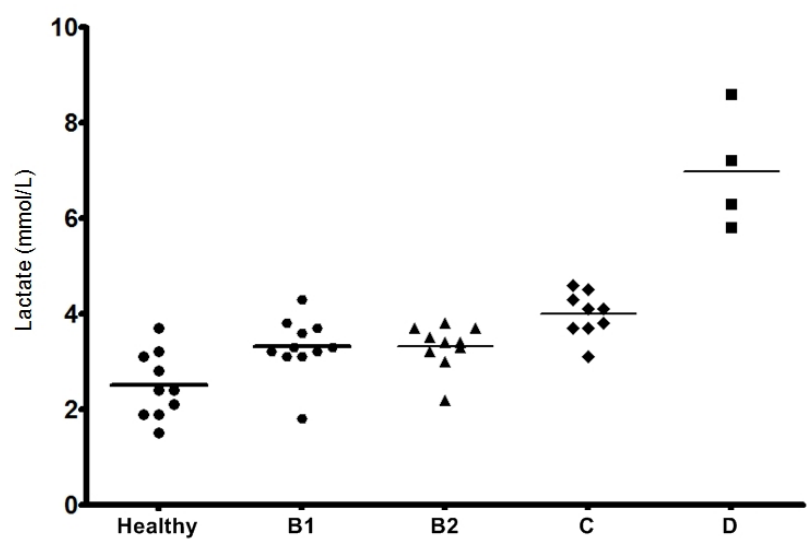

Fig.1. Medians of blood lactate concentration in healthy dogs and with myxomatous mitral valve disease (MMVD). While stages B1 and B2 animals are completely asymptomatic, dogs in either stage $C$ or stage D present overt clinical signs attributable to congestive heart failure. Significant differences were identified only between healthy and MMVD stages C and D.

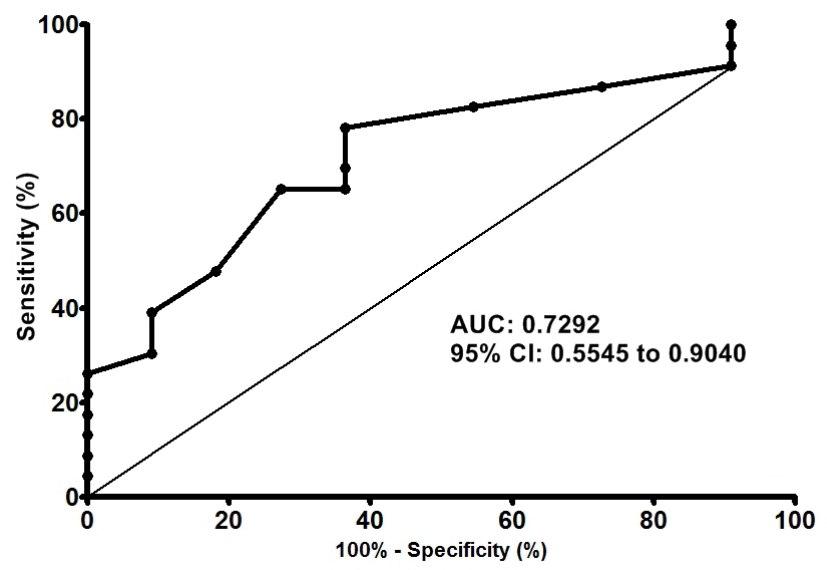

Fig.2. ROC curve used for calculation of the sensitivity and specificity of lactate to differentiate dogs with myxomatous mitral valve disease (MMVD) from either normal or remodeled hearts. The area under the curve indicated that the differentiation of such conditions was higher than expected by chance. blood pressure $(\mathrm{R}=-0.3146 ; \mathrm{P}=0.0374)$. Interestingly, a significant positive correlation was documented between lactate and the body temperature gradient $(\mathrm{R}=0.4439$; $\mathrm{P}=0.0025$ ). Figure 3 shows the scatter plots picturing the two most significant correlations found in our study. Specifically, for the stage D dogs, cephalic vein blood lactate concentration before treatment $(7.55 \pm 1.17 \mathrm{mmol} / \mathrm{L})$ was significantly higher $(\mathrm{P}=0.0044)$ than its concentration measured one day later $(4.00 \pm 0.81 \mathrm{mmol} / \mathrm{L})$ (Fig.4).

Regarding prognosis, only two dogs were censored over the study and the Kaplan-Meier curve showed the median time to decompensation (MTD) ascribed to heart failure to differ significantly according to blood lactate concentration at time of diagnosis (Fig.5). Animals with blood lactate $<3.5 \mathrm{mmol} / \mathrm{L}$, between 3.5 and $5.0 \mathrm{mmol} / \mathrm{L}$, and $>5.0 \mathrm{mmol} / \mathrm{L}$ had a MTD of 460,183 , and 57 days, respectively. Although statistical differences were not documented for the all-cause mortality, no dogs with lactate $<3.5 \mathrm{mmol} / \mathrm{L}$ at presentation died during the study, while dogs with lactate in the 3.5-5.0 range had a median time of 316 days until death, and those animals with the highest concentration of lactate lived a median of only 177 days.
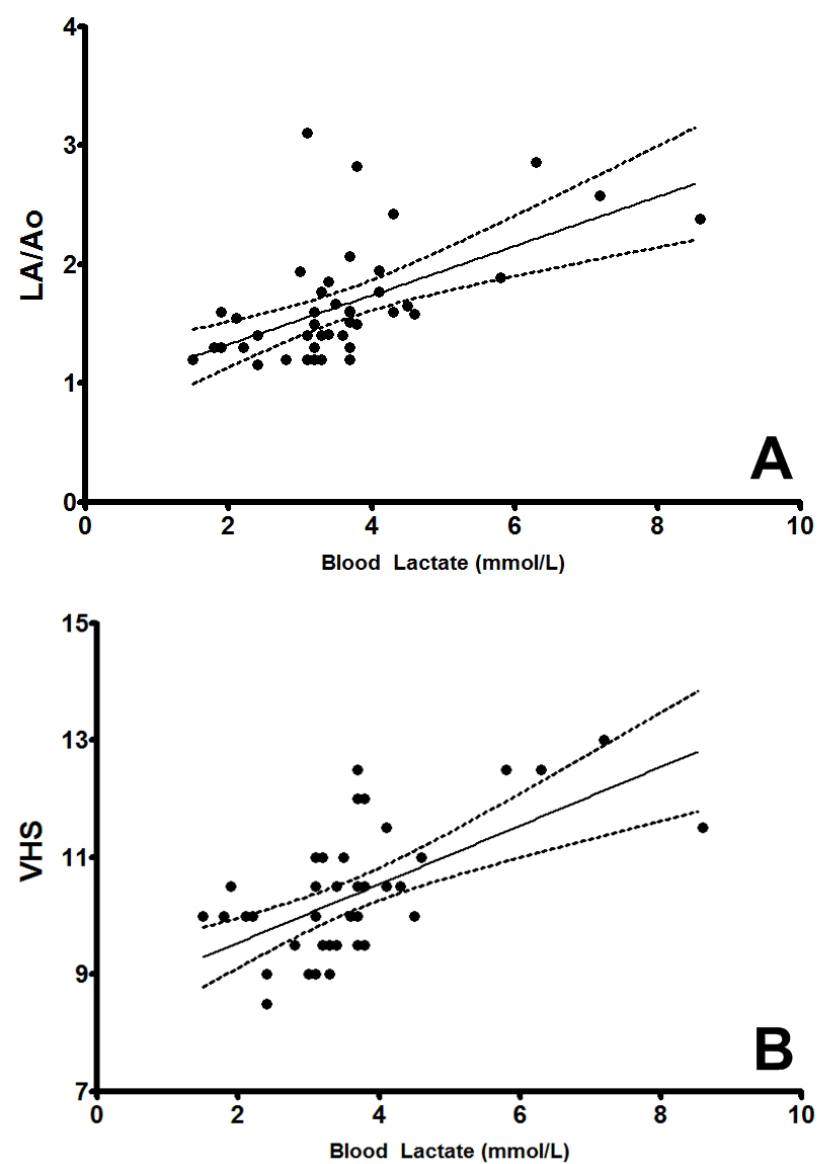

Fig.3. Scatter plots showing moderate positive correlation coefficients between blood lactate concentration and either (A) LA/Aorta ratio or (B) VHS in dogs. Dashed lines represent the $95 \%$ confidence intervals. 


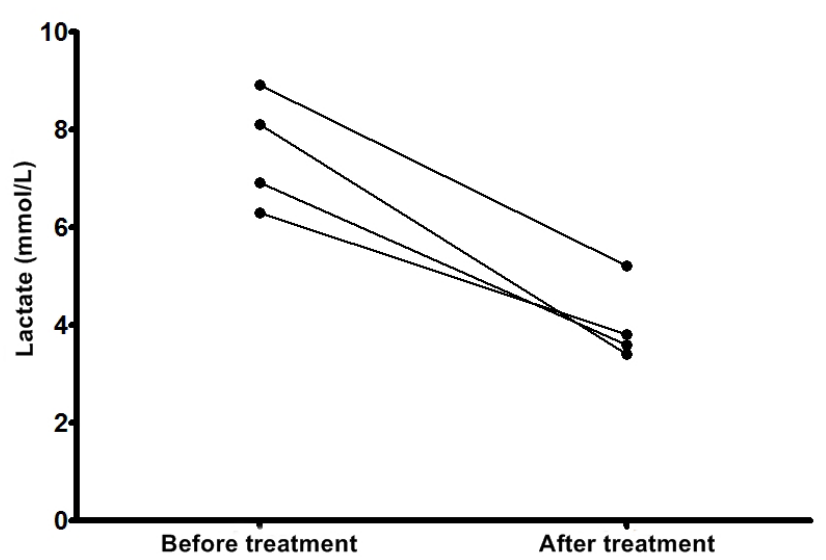

Fig.4. Graphic representation of the change in cephalic vein blood lactate concentration one day after diuretic treatment intended for cardiogenic pulmonary edema in stage D dogs.

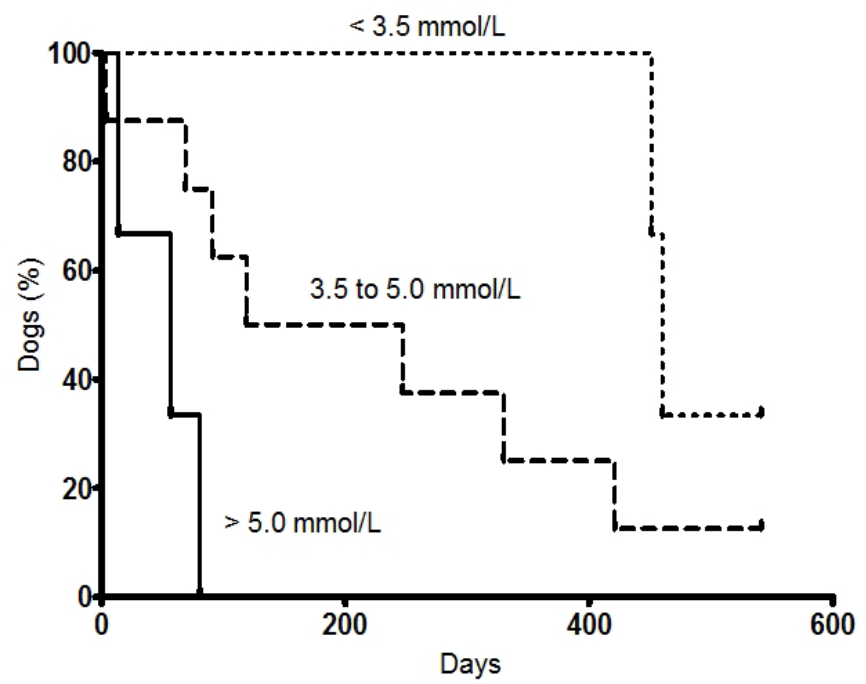

Fig.5. Kaplan-Meier curve using blood lactate concentration as the prognostic marker. Dogs with myxomatous mitral valve disease (MMVD) which lactate $<3.5 \mathrm{mmol} / \mathrm{L}$ at initial presentation required a median of 460 days to develop any clinical sign ascribed to heart failure, which was significantly longer than the median time necessary for the animals with higher lactate concentrations to become overtly symptomatic. Two dogs were censored during the study.

\section{DISCUSSION}

In recent years, biomarkers have gained popularity in veterinary medicine. The ideal biomarker has high sensitivity and specificity to diagnose any given condition and can be easily quantified in organic samples (Ladenson 2007, Allen \& Holm 2008, Baisan et al. 2016). In veterinary cardiology, some specific biomarkers have been advocated in distinguishing between cardiac and respiratory conditions. Also, some have proven to correlate with the progression of mitral valve disease, besides being surrogate markers for prognosis in dogs with cardiac maladies (Schober 2005, Sharkey \& Wellman 2013).
Lactate is not considered a cardiac-specific biomarker. Nevertheless, some of its advantages include not being cost-prohibitive, and the ease of determination. Also, the accumulation of lactate in the bloodstream might indicate an inappropriate tissue perfusion, which has been associated with the worsening of clinical conditions in patients with several diseases, especially those in intensive care units (Radcliffe et al. 2015). In this investigation, we sought to investigate the blood concentration of lactate in dogs with MMVD based on the premise that reduced cardiac output and the excessive activation of the sympathetic nervous system and the renin-angiotensin-aldosterone system are well known to cause an inappropriate distribution of blood throughout the body, therefore resulting in hypoxia and hyperlactatemia (Allen \& Holm 2008, Lisbeth et al. 2009).

In this study, blood lactate was shown to increase with the intensification of congestion, which is likely responsible for an increased hypoperfusion in those subjects. A mild systemic hypoperfusion is associated with a plasma lactate concentration ranging from 2.5 to $4.9 \mathrm{mmol} / \mathrm{L}$, while moderate and severe hypoperfusion results in lactate concentrations between 5 and $7 \mathrm{mmol} / \mathrm{L}$ and $>7 \mathrm{mmol} / \mathrm{L}$, respectively (Friedman et al. 1995). Our data clearly points to an increasing impairment in tissue oxygen delivery as congestive heart failure worsens, since healthy control dogs had a significantly lower blood lactate concentration as compared to MMVD dogs in stages C and D. Also, significant differences existed between the asymptomatic MMVD dogs (B1 and B2) and those with a history of pulmonary edema (D). A study that included 30 healthy and 48 dogs with varying diseases found a median lactate concentration of $1.9 \mathrm{mmol} / \mathrm{L}$ and $4.1 \mathrm{mmol} / \mathrm{L}$, respectively, which attested the diagnostic capacity of a point-of-care analyzer similar to the one used in this investigation (Thorneloe et al. 2007) When the jugular blood lactate was assessed in healthy and critically-ill dogs, another investigation found that $95 \%$ of the diseased dogs had a concentration higher than the mean concentration recorded for the control dogs (Lagutchik et al. 1998). This finding is quite like our results, which documented higher lactate values in animals with cardiac disease as compared to the canine reference range and the results found in our own normal dogs.

The echocardiographic data indicated changes attributable to the progression of valvular disease (Boon 2011). Similarly, lactate increased in accordance with the severity of volume-related cardiac remodeling, which was ascribed to the activation of compensatory mechanisms, including the renin-angiotensin-aldosterone system. The increased end-diastolic left-ventricular chamber and left atrium correlated positively with the augmentation of blood lactate concentration, pointing to the intensification of tissue hypoperfusion and the development of hyperlactatemia with the progression of cardiac disease. The hyperkinetic left ventricular wall and interventricular septum caused the fractional shortening to increase accordingly (Boon 2011), and that increase was also correlated with the changes in blood lactate concentration over time.

The positive significant correlation between heart rate and blood lactate may be explained by the increasing sympathetic stimuli that follows the progression of valvular disease and the development of signs ascribed to heart failure (Lisbeth et al. 2009) The upregulated sympathetic nervous system and the 
overactivation of the renin-angiotensin-aldosterone system are aimed at normalizing cardiac output and arterial pressure in subjects with cardiac disease, but eventually result in volume overload and ventricular remodeling.

Even though the electrocardiogram lacks sensitivity and specificity to accurately document chamber enlargement, ventricular remodeling might be responsible for the increased duration of QRS complexes found in MMVD dogs (Soares et al. 2005), which also correlated with the increasing lactate concentration observed with the progression of heart disease. Also, electrocardiographic changes suggestive of right heart enlargement were identified in this study. An increase in P wave amplitude might be observed in dogs with either pulmonary or airway diseases, as well as right atrial enlargement. Mitral insufficiency may lead to pulmonary hypertension, which in turn can result in right heart remodeling (Kellihan \& Stepien 2010). The correlation documented between blood lactate and the amplitude of $\mathrm{P}$ wave becomes clear when we consider that lactate levels were shown to increase in accordance with the progression of CHF and the severity of MMVD increases the likelihood of the animal developing pulmonary hypertension. Similarly, VHS increased in accordance with the progression of MMVD (Soares et al. 2005), resulting in a significant positive correlation with the blood concentration of lactate.

The difference between central and peripheral temperatures was previously shown to increase with the progression of tissue hypoperfusion (Sharkey \& Wellman 2013). This temperature gradient has been used to diagnose and monitor the treatment of people with abnormalities of systemic blood flow. While a central-peripheral temperature gradient $>7^{\circ} \mathrm{C}$ may indicate tissue hypoperfusion, the improvement in the patient's hemodynamic status is usually associated with the gradient ranging between $3-7^{\circ} \mathrm{C}$ (Vincent et al. 1988). Interestingly, this study found a significant positive correlation between the body temperature gradient and the blood lactate, which points to the intensification of tissue hypoperfusion in association with the progression of MMVD.

Even though systolic arterial pressure remained within the reference range in all dogs of this study, a reduction was documented with the progression of cardiac disease, attaining a negative correlation with the increasing lactate. Several conditions might be responsible for the inability of the compensatory mechanisms involved with both volume and pressure overload in keeping blood pressure stable when cardiac diseases progress to advanced congestive heart failure. That potentially includes excessive sympathetic stimulation and downregulation of adrenergic receptors, as well as the escalation of left-atrial regurgitation resulting in a reduced cardiac output (Kittleson \& Hamlin 1981, De Morais \& Schwartz 2005).

Most studies that measured blood lactate aimed at assessing hypoperfusion caused by any pathologic condition, as well as the response to its treatment (Nel et al. 2004, Allen \& Holm 2008) Specifically for the stage D dogs recruited into this investigation, blood lactate was measured before and after medical therapy intended for cardiogenic pulmonary edema. Indeed, the results showed a significant reduction of lactate concentration after diuretic therapy, pointing to an improvement in tissue perfusion.

Besides its applicability for monitoring critically-ill patients, including anesthetized subjects and those in shock in which tissue perfusion surrogates are warranted, lactate was shown to aid in prognostication (Zavariz et al. 2006). In our study, dogs with blood lactate concentration $<3.5 \mathrm{mmol} / \mathrm{L}$ needed a longer period of time to exhibit any clinical sign ascribed to heart failure, in spite of mitral valve being already degenerated. On the contrary, those with a concentration $>5.0 \mathrm{mmol} / \mathrm{L}$ at initial assessment became overtly symptomatic more prematurely. Although not significant, dogs with higher lactate concentrations tended to die sooner as compared with those that had lower concentrations. A study that investigated lactate in dogs with babesiosis found lactate to be a surrogate for survival since surviving animals had either the lowest lactate concentration before treatment or a lactate concentration that reduced over time when therapy was initiated (Nel et al. 2004). Another investigation that enrolled only dogs admitted for fluid therapy showed a significant association between mortality and a serial reduction in lactate concentration lower than $50 \%$ of its initial concentration (Stevenson et al. 2007). Also, lactate was shown to be a prognostic surrogate for children maintained in ICU owing to sepsis and septic shock (Allen \& Holm 2008). Finally, when the serum lactate levels were assessed in 394 patients surviving after a cardiac arrest, those subjects in which lactate was lower at time of admission showed a longer survival time when compared with those individuals that exhibited a still increased lactate after 48 hours (Kliegel et al. 2004).

Some of the limitations of this investigation include the small number of dogs enrolled, especially those belonging to stage D. Also, the addition of a more detailed assessment of tissue perfusion would allow determining whether the level of hyperlactatemia truly correlates with the magnitude of impairment in tissue perfusion ascribed to the deteriorating heart disease. Finally, we acknowledge that the prognostic study was limited because of the reduced duration of the study.

\section{CONCLUSIONS}

The results of this study suggest that dogs with myxomatous mitral valve disease (MMVD) have an impaired peripheral tissue perfusion that worsens with disease progression. This condition leads to the accumulation of lactate in bloodstream, and the increased concentration of blood lactate may be used as a surrogate for cardiac remodeling.

Dogs with an increased blood lactate concentration carried a worse prognosis regarding the time needed to develop overt clinical signs attributable to congestive heart failure.

Conflict of interest statement.- The authors have no competing interests.

Acknowledgments.- The authors thank Conselho Nacional de Desenvolvimento Científico e Tecnológico (CNPq) for the financial support of this study.

\section{REFERENCES}

Allen S.E. \& Holm J.L. 2008. Lactate: physiology and clinical utility. J. Vet. Emerg. Crit. Care 18(2):123-132. <http://dx.doi.org/10.1111/j.1476-4431.2008.00286.x>

Atkins C., Bonagura J., Ettinger S., Fox P., Gordon S., Haggstrom J., Hamlin R., Keene B., Luis-Fuentes V. \& Stepien R. 2009. Guidelines for the diagnosis and treatment of canine chronic valvular heart disease. J. Vet. Intern. Med. 23(6):1142-1150. <http://dx.doi.org/10.1111/j.1939-1676.2009.0392. x> <PMid:19780929> 
Baisan R.A., Rosa A.D., Loria A.D., Vulpe V. \& Piantedosi D. 2016. Cardiac biomarkers in clinical practice of dog and cat-a review. Human Vet. Med. Bioflux 8:50-58.

Boon J.A. 2011. Acquired heart disease, p.267-333. In: Ibid. (Ed.), Veterinary Echocardiography. 2nd ed. John Willey and Sons, New Jersey.

Buchanan J.W. \& Bücheler J. 1995. Vertebral scale system to measure canine heart size in radiographs. J. Am. Vet. Med. Assoc. 206(2):194-199. <PMid:7751220>

Friedman G., Berlot G., Kahn R.J. \& Vincent J.L. 1995. Combined measurements of blood lactate levels and gastric intramucosal $\mathrm{pH}$ in patients with severe sepsis. Crit. Care Med. 23(7):184-193. <http://dx.doi.org/10.1097/00003246199507000-00006>

Helliksson F., Wernerman J., Wiklund L., Rosell J. \& Karlsson M. 2016. The combined use of three widely available biochemical markers as predictor of organ failure in critically ill patients. Scand. J. Clin. Lab. Invest. 76(6):479-485. <http://dx.doi.org/10.1080/00365513.2016.1201850><PMid:27362714>

Kellihan H.B. \& Stepien R.L. 2010. Pulmonary hypertension in dogs: diagnosis and therapy. Vet. Clin. North Am., Small Anim. Pract. 40(4):623-641. <http:// dx.doi.org/10.1016/j.cvsm.2010.03.011 > <PMid:20610015>

Kittleson M.D. \& Hamlin R.L. 1981. Hydralazine therapy for severe mitral regurgitation in a dog. J. Am. Vet. Med. Assoc. 179(9):903-905.<PMid:7341606>

Kliegel A., Losert H., Sterz F., Holzer M., Zeiner A., Havel C. \& Laggner A.N. 2004. Serial lactate determinations for prediction of outcome after cardiac arrest. Medicine, Baltimore, 83(5):274-279. <http://dx.doi.org/10.1097/01. md.0000141098.46118.4c > <Mid:15342971>

Ladenson J.H. 2007. A personal history of markers of myocyte injury (myocardial infarction). Clin. Chim. Acta 381(1):3-8. < http://dx.doi.org/10.1016/j. cca.2007.02.039><PMid:17451663>

Lagutchik M.S., Ogilvie G.K., Hackett T.B. \& Wingfield W.E. 1998. Increased lactate concentrations in III and injured dogs. J. Vet. Emerg. Crit. Care 8(2):117-127.<http://dx.doi.org/10.1111/j.1476-4431.1998.tb00052.x>

Lima A., Jansen T.C., van Bommel J., Ince C. \& Bakker J. 2009. The prognostic value of the subjective assessment of peripheral perfusion in critically ill patients. Crit. Care Med. 37(3):934-938. <http://dx.doi.org/10.1097/ CCM.0b013e31819869db> <PMid:19237899>

Lisbeth H.O., Jens H. \& Henrik D.P. 2009. Acquired valvular heart disease, p.1299-1319. In: Ettinger S.J. \& Feldman E.C. (Eds), Textbook of Veterinary Internal Medicine. Elsevier Health Sciences, Philadelphia.
Morais H.A. \& Schwartz D.S. 2005. Pathophysiology of heart failure, p.914940. In: Ettinger S.J. \& Feldman E.C. (Eds), Textbook of Veterinary Internal Medicine. W.B. Saunders, Philadelphia.

Nel M., Lobetti R.G., Keller N. \& Thompson P.N. 2004. Prognostic value of blood lactate, blood glucose, and hematocrit in canine babesiosis. J. Vet. Intern. Med. 18(4):471-476.<http://dx.doi.org/10.1111/j.1939-1676.2004. tb02569.x><PMid:15320582>

Radcliffe R.M., Buchanan B.R., Cook V.L. \& Divers T.J. 2015. The clinical value of whole blood point-of-care biomarkers in large animal emergency and critical care medicine. J. Vet. Emerg. Crit. Care 25(1):138-151. <http:// dx.doi.org/10.1111/vec.12276> <PMid:25590562>

Schober K.E. 2005. Biochemical markers of cardiovascular disease, p.940947. In: Ettinger S.J. \& Feldman E.C. (Eds), Textbook of Veterinary Internal Medicine. 6th ed. Elsevier Saunders, Missouri.

Sharkey L.C. \& Wellman M.L. 2013. Use of lactate in small animal clinical practice. Vet. Clin. N. Am., Small Anim. Pract. 43(6):1287-1297. <http:// dx.doi.org/10.1016/j.cvsm.2013.07.012> <PMid:24144091>

Soares E.C., Larsson M.H.M.A. \& Yamato R.J. 2005. Chronic valvular disease: correlation between clinical, eletrocardiographic, radiographic and echocardiographic aspects in dogs. Arq. Bras. Med. Vet. Zootec. 57(4):436441. <http://dx.doi.org/10.1590/S0102-09352005000400003>

Stevenson C.K., Kidney B.A., Duke T., Snead E.C. \& Jackson M.L. 2007. Evaluation of the accutrend for lactate measurement in dogs. Vet. Clin. Pathol. 36(3):261-266. <http://dx.doi.org/10.1111/j.1939-165X.2007. tb00221.x ><PMid:17806074>

Thorneloe C., Bédard C. \& Boysen S. 2007. Evaluation of a hand-held lactate analyzer in dogs. Can. Vet. J. 48(3):283-288. <PMid:17436905>

Tilley L.P. 1992. Interpretations of Q R, S, T deflections, p.59-99. In: Tilley L.P. (Ed.), Essentials of Canine and Feline Eletrocardiography. 3rd ed. Lea and Febiger, Philadelphia.

Vincent J.L., Moraine J.J. \& Van Der Linden P. 1988. Toe temperature versus transcutaneous oxygen tension monitoring during acute circulatory failure. Intensive Care Med. 14(1):64-68. <http://dx.doi.org/10.1007/ BF00254125 > <PMid:3343431>

Wolf R., Camacho A.A. \& Souza R.C.A. 2000. Eletrocardiografia computadorizada em cães. Arq. Bras. Med. Vet. Zootec. 52(6):610-615. <http://dx.doi. org/10.1590/S0102-09352000000600010>

Zavariz S.M., Leite C.E., Pires M.G., Oliveira J.R. \& Nunes F.B. 2006. Laboratory markers of the septic shock. Sci. Med. 16:29-37. 